\title{
Terminology to Support Manufacturing Process Characterization and Assessment for Sustainable Production
}

\author{
Ian C. Garretson ${ }^{1}$ \\ Mahesh Mani² \\ Swee Leong ${ }^{2}$ \\ Kevin W. Lyons ${ }^{2}$ \\ Karl R. Haapala ${ }^{1 *}$
}

${ }^{1}$ Industrial Sustainability Laboratory, School of Mechanical, Industrial, and Manufacturing Engineering, Oregon State University, Corvallis, OR 97331

${ }^{2}$ Systems Integration Division, National Institute of Standards and Technology, Gaithersburg, MD 20899

*Corresponding Author: karl.haapala@oregonstate.edu

\begin{abstract}
Common terminology is essential for accurate communication among researchers, scientists, engineers, and other decision makers. To assist manufacturing process characterization, a common understanding of terminology is imperative for efficient and effective communication in industry; it can also facilitate automation and interoperability of software tools. Manufacturing process characterization enables the assessment and improvement of unit manufacturing processes, products, and systems from a sustainability perspective. To develop and implement sustainability-related standards and best practices in industry, naming conventions and definitions of common terms are needed. Presently, many terms used are ill-defined, vague, or overlap in meaning. Although there are ongoing standards efforts related to terminology identification and definition, an identified common set is yet to be developed.
\end{abstract}

The objective of this work was to facilitate ongoing standards development efforts by harmonizing the varied array of terms used to describe production processes. As a result of a review of the literature, a concise set of 47 terms focusing on process characterization and able to describe sustainable production was generated; terms unique to individual production processes were omitted. The terms were organized into six categories to define the overarching concepts: Scope, Boundary, Material, Measurement, Model, and Flow. Definitions of the terms were then derived from the literature in sustainable manufacturing and chemical and process industries, process characterization and planning, organization standards, and life cycle assessment and management.

The reported terms and definitions are not unique to sustainable production, and could foster widespread use of the concepts to improve the economic, environmental, and social performance of industry. In the future, the terminology described could be standardized through international standards organizations. Further, a rigorous review of research on manufacturing process characterization and process modeling in support of sustainable production is yet to be accomplished. Such a review would aid in organizing prior work by process type, perhaps by using a standard process taxonomy. Thus, a generalized, industry-relevant method for manufacturing process characterization could emerge to support sustainability assessment, and could be implemented through software applications accessible to a variety of users.

\section{Keywords}

Process characterization, terminology, sustainable production, process modeling, unit manufacturing process, manufacturing

\section{Introduction}

Production is often the source of many environmental and ecological impacts, making it a focus of sustainability-related research, reports, and legislation. Environmental legislation began to appear in the U.S. in the late 1940s with the Water Pollution Control Act (1948). In the 1960s the Clean Air Act (1963) was followed by National Environmental Policy Act (1969), which legislated the enforcement of early sustainability policies. Soon after, in 1970, Environmental Protection Agency (EPA) came into being (Richardson and Wood, 2006). Similar laws were enacted globally in the same time frame, e.g., Japan's Pollution Diet (1970), and similar agencies were created, e.g., West Germany's Federal Environmental Agency (1971) (Richardson and Wood, 2006). International efforts arose as meetings and subsequent reports, e.g., UN

(C) 2016. This manuscript version is made available under the Elsevier user license

http://www.elsevier.com/open-access/userlicense/1.0/ 
Conference on Human Environment (1972), the Brundtland report (1987), Earth Summit in Rio (1992), and Agenda 21 (1992). The Brundtland report (1987) was especially significant since it proposed a definition for sustainable development as "development which meets the needs of the present without compromising the ability of future generations to meet their own needs."

Elkington (1997) posited that businesses must consider both natural and social capital, along with economic capital, in their management plans to achieve a positive triple bottom line (people, profit, and planet). Thus, the Brundtland definition was expanded to include multiple dimension, and was adapted by Dyllick and Hockerts (2002) to address corporate sustainability as "meeting the needs of a firm's direct and indirect stakeholders (such as shareholders, employees, clients, pressure groups, and communities), without compromising its ability to meet the needs of future stakeholders as well."

The new century saw a change in the use of sustainability as a noun to sustainable as an adjective, indicating a conceptual shift in thinking of sustainability as an end goal to sustainability as an attribute of industrial products, systems, and practices. Sustainable design, as an engineering function within industry, for example, was expressed as "the design of human and industrial systems to ensure that humankind's use of natural resources and cycles do not lead to diminished quality of life due either to losses in future economic opportunities or to adverse impacts on social conditions, human health and the environment" by Mihelcic et al. (2003). Sustainable manufacturing was defined decade later by the U.S. Department of Commerce (DOC) (2013) as "creation of a manufactured product with processes that have minimal negative impact on the environment, conserve energy and natural resources, are safe for employees and communities, and are economically sound." These two definitions reflect the ideas earlier presented in the Brundtland report and by Elkington. Both definitions assert that there are negative environmental, economic, and social impacts related to the production industry that must be reduced to sustain and support the development of global civilization.

As a first step toward reducing such negative impacts, many companies have developed sustainability metrics and indicators that quantify the economic, environmental, and social performance of business practices (Feng and Joung, 2011). To quantify sustainability performance, life cycle assessment (LCA) methods, which have been implemented in numerous software tools, are commonly used. However, these methods are often opaque, costly, and time consuming; while existing tools can provide performance assessments, they offer little guidance for performance improvement. Reap et al. (2008a, 2008b) reported that challenges arise due to information about and use of the functional unit (Section 4.6.1), in addition to system boundary definitions, allocation and flow analysis, and the subjectivity introduced by aggregation of impact data.

To address these problems, more comprehensive, sustainable product design methods have been developed, e.g., Chiu and Kremer, 2011; Ramani et al., 2010, but these often omit detailed evaluation of production process and system performance. Unit manufacturing process (UMP) characterization can be used to assist detailed production system assessments, and thus fill this gap. UMP modeling and development of cost effective, environmentally friendly UMPs were identified by the National Research Council (NRC) (1995) as two key areas for engineering research and innovation. A generalized UMP characterization method was subsequently demonstrated using specific case studies, e.g., Dahmus and Gutowski, 2004; Jiménez-González et al., 2000; Murphy et al., 2003, and was developed more recently into defined methods, e.g., Eastwood and Haapala, 2015; Kellens et al., 2012a, 2012b; Overcash and Twomey, 2012. Unique case studies are still being published, e.g., Dornfeld and Linke, 2012, to support methodological development efforts.

In sum, in today's competitive global market, manufacturers are being compelled to create and deliver high quality products in a cost effective and socially responsible manner, while reducing the environmental impacts of their activities. Thus, a key challenge lies in effectively quantifying and communicating sustainability performance of UMPs to facilitate improvement decisions. Current industry practices to compute sustainability performance are not standardized. Consequently, these practices rely on ad hoc information and non-uniform methods to calculate the performance of production processes and equipment. There is growing interest from industry, government agencies, and standards development organizations to change this situation by developing sustainability-related standard guides to facilitate such communication and decision making.

One such effort is being pursued by ASTM International $(2016,2014)$. The scope of the ASTM sustainable manufacturing standards (currently in the form of work items) addresses the evaluation aspects, terminology, characterization of manufacturing processes, and classification of waste at manufacturing facilities. The guides currently being developed are envisioned to assist manufacturers in characterizing manufacturing processes for sustainability and to support relevant decision making. Transferring sustainability-related standards and guides to the industry, however, requires a common language (terminology and definitions). Presently, many terms used in the area of sustainable manufacturing are illdefined, vague, or overlap in meaning. Although there are ongoing terminology-related standards efforts, including those undertaken by ASTM, an identified common set of terms and definitions is yet to be developed. 
Thus, the objective of this paper is to define standardized language for UMP characterization that can be used to support sustainability assessment of products, production processes, and production systems. Detailed UMP characterization can be used as a component of bottom-up analysis approaches to conduct product sustainability assessments. Because an overarching aim is to enable broadly usable sustainable production assessments, the terminology is identified primarily from sustainable-production and life-cycle-assessment literature. This literature was selected to ensure definitions appropriate to the contextual domain under study. Many of the terms have commonly accepted definitions, which are included here for completeness. While we recognize the need for supporting ontologies and methods for UMP characterization, addressing that need is beyond the scope of this paper.

\section{Method for Terminology Definition}

Seuring and Müller (2008) reported that literature reviews accomplish two objectives: "first, they summarize existing research by identifying patterns, themes and issues. Second, this helps to identify the conceptual content of the field and can contribute to theory development." From this viewpoint, the goals of the literature review herein are 1) to summarize the language and concepts used in UMP characterization for sustainability assessment and 2) to enable the development of supporting theory, methods, and industrially-relevant tools. Themes from the field will arise as a consequence of this goal. Beruvides and Omachonu (2001) described a ten-step process that is adapted to assist in the literature review. The first three steps ( 1 to 3 ) of their process direct the early stages of the literature search. The next four steps (4 to 7$)$ describe article organization. The eighth step (8) analyzes the data and content using several methods. The next two steps (9 to 10) address the identified gaps, reporting, and actions. The steps undertaken in the literature review presented here modifies this approach as follows:

1. Review literature to identify relevant areas for terminology search

2. Generate initial set of key terms and corresponding references

3. Identify explicit definitions that are self-contained and clear

4. Generate a matrix of terms and definitions to categorize the terminology

5. Review the matrix to identify gaps and overlaps

6. Check and harmonize the terminology

Since the purpose of the review is to identify, define, and harmonize terminology, rather than to identify broader themes and directions, the article organization steps specified by Beruvides and Omachonu are not necessary. First, relevant sources for definitions were identified from several research areas including life cycle assessment and management, manufacturing process modeling, chemical and process industries, sustainable policy, organizational standards, and process planning. Definitions that were explicitly stated in the references were adopted; literature that made use of a term, but did not define it explicitly were not used. An evolutionary method was used throughout the review to select and organize the relevant terminology from the body of research. Categories identified were relevant to aspects of UMP characterization, sustainability assessments, and the general patterns of the terminology. Terms that did not fit into a defined category were initially excluded from the list, and were added as new terms or synonyms as the review and harmonization proceeded.

The initially defined categories were Boundary, Data, Decision, Measurement, Policy, Process, and General. From these categories, the Data category was combined with the Measurement category, since few relevant data terms were identified in the review. The Policy category was combined with the General category, since the focus of the review was on modeling and assessment, and not company or government policy. To better define several higher-level concepts, the categories of Flow, Scope, and Taxonomy were added as the review proceeded. Thus, the second set of categories included Boundary, Flow, Material, Measurement, Model, Process, Scope, and Taxonomy. As the review proceeded, the Process and Taxonomy categories were found to be redundant, in that the terms included could be better attributed to the Flow, Model, and Scope categories. The final set of categories defined became Boundary, Flow, Material, Measurement, Model, and Scope. While others could be defined, this categorization approach was found to be suitable in organizing the terminology identified.

In deciding whether to include a term in the categorization set for further research and definition harmonization, the primary criterion was the term's relevance in answering the question, "How is a unit manufacturing process described?" As the categorization of terms proceeded, some terms emerged as synonyms for other identified terms. These synonyms aided in further defining the meaning of each particular term. Based on the references used to identify key terms and synonyms, definitions were generated and harmonized for each identified key term. In many cases, definitions previously established in literature were found to be suitable and were not modified. 


\section{Literature Review}

Embracing sustainability has been a concerted effort arguably since the Brundtland Commission presented its definition of sustainable development, and, prior to that, as less connected elements of environmental and social development initiatives. Society has begun addressing and incorporating sustainable development into research and common practice through the use of indicators (Parris and Kates, 2003). More broadly, sustainability has been incorporated into the development of a wide array of technologies and systems, including sustainable energy generation (Dincer, 2000), sustainable mineral processing (McLellan et al., 2009), sustainable construction (Ortiz et al., 2009), and sustainable supply chains (Seuring and Müller, 2008). Many reviews of the research literature have been completed from different viewpoints, including sustainable production perspectives, corporate perspectives and challenges (Arena et al., 2009; Rusinko, 2007), global manufacturing challenges (Gutowski et al., 2013; Jovane et al., 2008), discrete product/process/system challenges (Haapala et al., 2013), and LCA integration into manufacturing decision making (Westkämper et al., 2000). Literature reviews have been completed for sustainable chemical industry perspectives (Jenck et al., 2004; Jiménez-González et al., 2011); and for manufacturing process modeling, e.g., general approaches, (Duflou et al., 2011; Mani et al., 2014), machining (Ehmann et al., 1997; Guo et al., 2009; Jayal et al., 2010), metal forming (Dixit et al., 2011), and dry processing (Defraeye, 2014).

While the domains of these reviews overlap, they do not completely capture the terminology of sustainable UMP modeling. The following sections outline previous review articles related to sustainable UMP modeling, and move from broad concepts to specific applications. The sections present terminology-related work aligned with sustainable practices in the manufacturing and chemical and process industries, followed by a more-specific process characterization perspective. Based on the review, key terms and corresponding papers used in defining the terms are summarized. It is revealed that a common theme of prior studies shows that increasing global competition is driving the need for more sustainable practices.

\subsection{Sustainability Practices in Manufacturing}

Notably, an article by Glavič and Lukman (2007) developed definitions of terms for policy and decision making related to sustainable production. Press (2007) stated that policy will result in incremental improvements, but will not lead to acceptance of best available technologies (BATs). Both papers posited that voluntary action taken by firms and widely disseminating information relating to technology use brings about the greatest improvement. Press pointed out that research is needed to determine the effects that policies have on production improvements. Hahn and Kühnen (2013) evaluated the determinants of sustainability reporting in business and academia; they concluded that corporation size, visibility, and sector-affiliation were the most significant factors. Furthermore, Hahn and Kühnen identified research gaps, which included a need for 1) investigating the impact of report quality on stakeholder perception and understanding and 2) understanding the influence of regulation and governance on reporting. Kunz et al. (2013) investigated the natural sciences, engineering, and management literature to determine the intersection of human and engineered systems, which they termed coupling for sustainability, from both the technical and social perspectives. Kunz et al. argued that industrial sustainability has traditionally addressed technical systems, for example through energy efficiency initiatives. They suggested that incorporation of strong human coupling into research and industrial practice is needed. Stated areas of research included identifying and measuring strong coupling and determining ways to move from weak to strong coupling.

Implementation of sustainability policy in manufacturing has largely been evaluated using LCA to assess environmental impacts (Hauschild et al., 2005). Westkamper et al. (2000) analyzed the assessment and management of products from a life-cycle perspective and reviewed the intelligent manufacturing system (IMS) concept. They concluded that industry should use LCA to assimilate broad implications into corporate decision making, to enable organizations to provide more sustainable products, and to encourage more widespread use in developing countries. Finnveden et al. (2009) reviewed LCA practices and found that aspects of the method had significantly matured with the development of databases, quality assurance, consistency, and harmonization. However, they found more improvements were needed, including aspects of goal and scope definition, resolving differences between attributional and consequential LCAs, developing methods for more accurate impact assessments on ecosystem services, and prioritization of database development. Pryshlakivsky and Searcy (2013) investigated the development and improvement of the ISO14040 LCA standard by the International Organization for Standardization (ISO). They noted, while LCA has grown rapidly, a systematic, non-expert tool is required for incorporating the analyses into more fields of study. They also concluded that evaluation of the functional effectiveness of the standards is needed.

Several reviews have focused on sustainable manufacturing practices. Jovane et al. (2008) asserted that competitive sustainable manufacturing (CSM) must be implemented globally for manufacturing and services industries to address growing economic, social, environmental, and technological (ESET) challenges. They posited that CSM is needed for continued growth without depleting ESET resources. Arena et al. (2009) addressed sustainability from an operational 
point of view through an in-depth analysis of 1) sustainability definitions within different performance areas, 2) sustainability tools within different performance areas, 3) quantitative and non-quantitative measurement methods, and 4) indicator completeness. Hossain et al. (2008) reviewed existing pollution-prevention frameworks in both the design and retrofit stages. Using LCA, they developed an evaluation framework to determine the best pollution-prevention designs and technologies. Ilgin and Gupta (2010) analyzed progress made in environmentally conscious manufacturing and product recovery (ECMPRO) since Gungor and Gupta's similar work (Gungor and Gupta, 1999). Suggested research areas included product life cycle, disassembly, material recovery, remanufacturing, and pollution prevention. Among others, the authors identified a need for environmentally conscious design methodologies that integrate design of products and processes, a need for strategic models that go beyond operations and tactics of firms to analyze the technological and organizational dynamics of ECMPRO systems, and, finally, a need to incorporate these into engineering curricula.

Similarly, Haapala et al. (2013) investigated engineering research needed to support sustainable manufacturing, including the influence of metrics on design and manufacturing decision making, research opportunities for various manufacturing processes, and manufacturing-system and supply-chain-planning issues. Gutowski et al. (2013) analyzed the global carbon emissions caused by manufacturing and investigated the five major materials contributing to energy consumption and carbon emissions: 1) iron and steel, 2) cement, 3) plastics, 4) paper, and 5) aluminum. Most recently, Bolis et al. (2014) claimed that the term sustainable development has taken on too many meanings and needs to be redefined. They developed a sustainable development with an axiological perspective (SD-AP) model to guide the discussion for redefining sustainable development. The model incorporated the triple bottom line, generational needs, and value-based decision making, thus creating an integrated perspective. Ibáñez-Forés et al. (2014) analyzed previous methodologies for selecting the best available technologies (BATs) for sustainable practices and subsequently developed a methodology for doing so. They found that sensitivity analysis should be applied more throughout BAT assessment, not solely in the weighting stages. Also, they posited that decision makers should form multidisciplinary teams to remove bias from weighting criteria.

\subsection{Sustainability Practices in the Chemical and Process Industry}

While the focus here is on sustainable manufacturing process characterization, such efforts are not limited to discrete part manufacturing, but are also applicable to chemical processes. Reviews of sustainability practices in the chemical and process industry have been reported. In fact, the fundamental process analysis concepts for discrete product manufacturing were derived from chemical process analysis (Jiménez-González et al., 2000), and involve discretizing a process flow into unit steps, modeling the processes individually, and aggregating the results to analyze the system holistically. Based on the principles of green chemistry, Anastas and Zimmerman (2003) developed the twelve principles of green engineering, which are applicable to product manufacturing. Allen and Shonnard (2001) instructed chemical engineering students on environmentally conscious chemical-process design utilizing sustainable process characterization tools. Their text describes sustainability analysis using principles of unit process modeling, green chemistry, flow analysis, cost accounting, industrial symbiosis, and product evaluation using LCA.

Cano-Ruiz and McRae (1998) reviewed approaches for incorporating environmental issues as cost tradeoffs into the design of chemical processes. Among the needs identified, the most important was a change in attitude to view the environment as an objective, rather than a constraint. Marteel et al. (2003) stated that evaluation of an entire production operation is needed to minimize overall process hazards. They identified needs for research into processes based on catalysts that enable selective chemistry, deactivation of catalysts, use of benign reaction solvents, and simplified separation operations. Jenck et al. (2004) claimed that sustainable industrial chemistry had already been implemented in engineering curricula and commercial practice. The authors found investment in new technology to be the largest economic and regulatory hurdle, and identified several focus areas for future work, including industrial biotechnology and new process development (e.g., new reactor configurations). Jiménez-González et al. (2011) described the top green chemistry research areas identified by the American Chemical Society (ASC) Green Chemistry Institute (GCl) Pharmaceutical Roundtable in 2005: continuous processing, bioprocesses, separation and reaction technologies, solvent selection, recycling and optimization, process intensification, and integration of LCA. Nikolopoulou and lerapetritou (2012) reviewed sustainable chemical supply chains in the areas of energy conservation, waste management, and water management. They identified several supply chain challenges, including numerical difficulties during simulation and optimization, development of stochastic models for environmental impacts, and definition of performance measures.

\subsection{Manufacturing Process Characterization}

Prior research has investigated UMPs (e.g., machining and injection molding) under the lens of sustainability. Since there are myriad types of UMPs, many of which have been investigated, Kellens (2013) performed a review of many studies; the intent is not to review these studies here. In general, the studies have focused on process modeling of specific phenomena and do not generalize to methods that facilitate sustainability characterization. Ehmann et al. (1997), for 
example, examined modeling of dynamic cutting forces in machining processes. They observed that disparate models arise from the availability of numerous methods and that future work will add modeling complexity due to the incorporation of more machining phenomena. Similarly, Guo et al. (2009) analyzed machining processes and material modeling for hard metals including steel, titanium, and nickel alloys. They identified future work in microscale and nanoscale machining modeling, stress analysis and prediction, and new computational methods to reduce analysis time. Dixit et al. (2011) generalized process modeling as three steps: representing process mechanics analytically, modeling material behavior, and developing the solution method. Future work included the need for expanding models for multi-scale modeling and development of hybrid computational methods.

As alluded to above, UMPs can be improved throughout industry to reduce environmental impacts and improve sustainability performance. Jayal et al. (2010) reviewed modeling and optimization for sustainable manufacturing products, processes, and system levels, including dry, near-dry, and cryogenic machining of various metals. Research needs included rapid assessments for optimal product design and development of hybrid models to reduce data requirements while maintaining accuracy of results. Duflou et al. (2011) identified several shortcomings of traditional LCA in supporting analysis of UMPs, including three critical false assumptions, i.e., impacts of the product manufacturing phase is negligible, machine energy use is constant, and the impact of auxiliary process equipment can be neglected. They analyzed unit process life cycle inventories (UPCLI) and reported that the assessment method developed by the Cooperative Effort on Process Emissions in Manufacturing (CO2PE!) Initiative addresses several of the shortcomings by creating detailed analyses of UMPs.

To support process energy analysis, Defraeye (2014) reviewed advanced computational modeling approaches for drying processes. The article focused on porous materials (food), and identified needs for multi-scale and material properties modeling along with incorporation of models into a software platform. This work highlights the broader need for UMP characterization; it is not limited to any one industry (e.g., metals production). Mani et al. (2014) assessed the current practices for sustainability analysis of manufactured product and determined that current methods are ad hoc and do not account explicitly for UMPs. They focused on environmental aspects and reported prior manufacturing process classifications, sustainable manufacturing indicators, computable metrics, information models, and software tools. In addition, they documented an approach to facilitate sustainability characterization for UMPs. Given the existing disparate work in UMP analysis, as well as the infancy of process characterization for sustainability assessment, the following sections strive to identify terms and harmonize their definitions in support of sustainable manufacturing assessment, using the procedure described above (Section 2).

\subsection{Summary of Papers Used for Term Definitions}

The references used to define terms were derived from a variety of research areas, which included life cycle assessment and management, sustainable process modeling, chemical and process industry, sustainable policy, organizational standards, and process planning. The terms have been previously defined in various research domains, but harmonized definitions have not emerged. Tables 1-6 provide cross references for the references used to define specific terms. The terms have been categorized into six groupings as shown in Figure 1: Scope, Boundary, Material, Measurement, Model, and Flow.

\section{Discussion of Terminology}

The terms defined herein are derived from multiple references where possible. Explicit definitions for many terms were identified, although not all definitions for a single term were the same. When different definitions were provided, harmonized definitions were created based on the notions of Block (2001). Those notions state that many terms have vague meanings and each author's use has different connotations, until formal definitions are made. Our approach for creating harmonized definitions begins by identifying the most encompassing and relevant definitions for each term. This was accomplished by 1) adopting one definition directly from a source or, when that is not possible, 2) creating a harmonized version that references the other definitions. Where definitions were referenced directly, little to no discussion is included below; the quoted definition is reported in the corresponding table within each category.

Manufacturing involves the creation of discrete products, whereas processing is a sequence of chemical unit operations to produce chemicals continuously or in batches. Production can encompass both manufacturing and processing. Similarly, a unit operation and a unit process can be distinct (Shreve, 1954). A unit operation is a basic physical operation (e.g., reaction, separation, mixing, heating, cooling, fluid transport, and mass transfer), while a unit process involves a chemical conversion (e.g., oxidation, reduction, and esterification).

The terminology was categorized into six groupings (Figure 1) with the intention to convey the concepts of UMP characterization for sustainability assessment. A brief summary is provided here, and more details can be found in the ensuing sections. First, Scope terminology helps to identify the overall goal of a sustainability study. Next, Boundary 
terminology is used to clarify the boundary conditions for input and output flow modeling. Third, Material terminology specifically describes the physical media in product production. Fourth, Measurement terminology relates to the quantitative values that support sustainability assessment. Next, Model terminology defines different models and model attributes. Finally, Flow terminology describes the movement of energy, materials, and information within a production system. Terms were organized using an evolutionary method; categories that were changed, merged, or dropped included Data, Decision, Policy, Process, and Product. In some cases, when the terms did not fit well into a specific category, the best fit was selected; for example, allocation (an attribute of Flow) is included in the Boundary category, functional unit (which defines Scope) is included in the Flow category, sustainable manufacturing (a general term) is included in the Scope category, and characterization factor (used in Modeling) is included in the Measurement category.

(Insert Figure 1)

\subsection{Scope Terminology}

The Scope terminology helps identify the UMP and type of production environment being examined. The terms within the Scope terminology discussed below include: sustainable manufacturing, manufacturing system, hybrid process, unit manufacturing process (UMP), sub-process, machine, continuous manufacturing process, discrete part manufacturing process, and batch manufacturing process. Table 1 summarizes the harmonized definitions of the Scope terminology, including relevant synonyms.

\subsubsection{Sustainable Production}

Sustainable is defined as "state of the global system, including environmental, social, and economic aspects, in which the needs of the present are met without compromising the ability of future generations to meet their own needs" (ISO, 2014; World Commission on Environment and Development, 1987). Manufacturing is defined to be the creation of products, goods, and services (Mani et al., 2014; US Department of Commerce 2013; Zhang et al., 2014) using a system of processes (Glavič and Lukman, 2007; Veleva and Ellenbecker, 2001; Zhang et al., 2015). Sustainable manufacturing or, more broadly, sustainable production emerges by evaluating and addressing the impacts of a product or process comprehensively, including the conservation of energy and natural resources, safety of employees and surrounding communities, and economic viability (Glavič and Lukman, 2007; Mani et al., 2014; US Department of Commerce, 2013; Veleva and Ellenbecker, 2001). These three supporting aspects (environmental, social, and economic) are called the three pillars of sustainability (Zhang et al., 2015).

\subsubsection{Production System}

A production system contains processes, activities, and devices (Duflou et al., 2012; Eastlick and Haapala, 2012; ISO, 2006; Kellens et al., 2012a; Zhang et al., 2015). Several authors noted that the UMPs are organized in sequence (Duflou et al., 2012; Kellens et al., 2012a), while others reported that the UMPs are interrelated (ISO, 2006; Zhang et al., 2015). Finally, many authors stated that a transformation occurs (ISO, 2006; Zhang et al., 2015), causing the inputs to be converted into the outputs. As part of a production system, the terms manufacturing system and process system are similar, but there are subtle differences as discussed previously in this section.

\subsubsection{Hybrid Process}

Hybrid processes were recognized by Duflou et al. (2012) and included here because of the uniqueness of these processes. A hybrid process can be described as a combination of processes completed on a single machine (Duflou et al., 2012). This is distinguished from a production cell, where multiple machines in close proximity are utilized in sequence to complete a series of operations. Like a production cell, however, each process within a hybrid process can be analyzed separately (Duflou et al., 2012). Notably, a hybrid process is dissimilar to a UMP with integrated support equipment, as defined in Section 4.1.4.

\subsubsection{Unit Manufacturing Process (UMP)}

A unit manufacturing process (UMP) is identified with two common themes. The first considers that the UMP is the smallest element in manufacturing (ISO, 2006; Zhang et al., 2015), also called individual steps (Mani et al., 2014; US National Research Council, 1995). This consideration provides a definition for the term "unit." The second consideration identifies a transformation to add value (Mani et al., 2014; US National Research Council, 1995), either from inputs to outputs (ISO, 2006; Kellens et al., 2012a; Mani et al., 2014; US National Research Council, 1995), or with more specific shape, structure, or property transformations (Mani et al., 2014; Overcash and Twomey, 2012).

Overcash and Twomey (2012) noted that UMPs are generally interchangeable, meaning that processes accomplishing the same function can be replacements for each other. The differences in functionality between different UMPs were not addressed directly in prior research, but some authors addressed the differences indirectly through transformations. Thus, 
identification of different taxonomological transformations was included in this definition. The definition in Table 1 also notes that UMPs use various forms of technology, such as one or multiple machines. Although it is the smallest element in production, there are instances where multiple machines are used to accomplish one activity; however, dissecting the process further reveals no more underlying transformations.

\subsubsection{Sub-Process}

A sub-process is recognized to be a sub-level of a process (Mani et al., 2014). Note that sub-processes do not perform recognizable taxonomological transformations, whereas processes do. This characteristic helps to distinguish that a subprocess acting within a process is different from a process within a hybrid process. A sub-process is also distinguished from a machine, since a sub-process activity can be completed without a machine or with one or several machines.

\subsubsection{Machine}

A machine performs a unit manufacturing process (Duflou et al., 2012). A machine is a device that performs work or makes work easier, and is a combination of rigid bodies that usually overcome a resistant force (Larousse, 1995; McGraw-Hill, 2003; Oxford University Press, 2010). Synonyms include device, equipment, mechanism, instrument, and tool. Support equipment that does not actually perform the UMP is also included in the definition. Machine is defined here to separate the meaning from a UMP or sub-process, since each UMP or sub-process may require several machines. For example, a penetrant testing process requires the use of a penetrant delivery mechanism, a powder delivery mechanism, a drying mechanism, and an ultraviolet emitting lamp for inspection. Similarly, the common three-axis milling machine has four motors: one for each axis and one for the spindle. While the milling machine is considered a machine, each motor can also be defined as a machine. The UMP can consist of several machines located in close proximity to form a manufacturing cell, or can be embodied within a single, monolithic machine that would convey parts through each stage in the process.

\subsubsection{Continuous Manufacturing Process}

Continuous manufacturing process was defined based on the definition of Duflou et al. (2012). Their definition was modified to clarify that continuous manufacturing processes are measured using flow rates.

\subsubsection{Discrete Part Manufacturing Process}

Discrete part manufacturing process was defined based on the definition of Duflou et al. (2012). Their definition was modified as discussed in Section 4.1.7 to emphasize the contrast between continuous and discrete part manufacturing processes.

\subsubsection{Batch Manufacturing Process}

A batch manufacturing process recognized here is one that processes several products at the same time (Hopp and Spearman, 2011). This is different from the common batch queuing system, where products are transported or loaded as a batch, and subsequently processed individually. Hopp and Spearman (2011) referred to this as a true batch workstation. Batch processing occurs in the chemical and process industry, where a discrete volume or mass of the chemical is processed in a batch.

\section{(INSERT TABLE 1)}

\subsection{Boundary Terminology}

Boundaries are needed to guide the decision-making process, e.g., an injury rate can be associated with one machine in a multi-machine process and can muddle the results for an assessment of the whole process. During sustainability assessment, identifying the system boundaries is necessary not only for immediate decisions to be made from the study, but also to facilitate future studies and comparisons. Terms included within the Boundary category include: boundaries, input, ancillary input, output, and allocation. Table 2 summarizes the harmonized definitions of the Boundary terminology.

\subsubsection{Boundaries}

Boundaries are identified based on the 1) evaluation criteria (ISO, 2006; Zhang et al., 2015), 2) level of detail of the investigation (Duflou et al., 2011; Kellens et al., 2012a; Veleva and Ellenbecker, 2001), 3) inputs and outputs considered (Duflou et al., 2011; Kellens et al., 2012a), and 4) a specific goal for investigating, measuring, or studying the system (Duflou et al., 2011; Kellens et al., 2012a; Veleva and Ellenbecker, 2001; Zhang et al., 2015). Notably, several authors specify well-defined boundaries before examining a UMP (Duflou et al., 2012, 2011; Kellens et al., 2012a). Doing so creates highly compatible process models, and this type of standardization should be helpful for model composability. 


\subsubsection{Input}

An input is identified as a material, intermediate product, energy, or work (Haapala et al., 2013; ISO, 2006) that enters a UMP (ISO, 2006). Note that intermediate products could be inputs to a subsequent UMP. The authors recognize that information or knowledge, e.g., in the forms of signals and controls, also enter the defined boundaries. A boundary can range from one process or machine to an entire production system. Thus, the definition was expanded to include information that enters the boundary of the system under study. The McGraw-Hill Dictionary of Scientific and Technical Terms (2003) identifies inputs as resources converted by a system, but it should be noted that all inputs that enter a process might not be converted as a result of the process. Examples of non-converted input include cyclically used water or coolant, assuming that it does not become dirty or leave the system, or machine settings that are input and used for control, but are not converted into a feedback output.

\subsubsection{Ancillary Input}

Ancillary input was defined using the definition of ISO (2006).

\subsubsection{Output}

Haapala et al. (2013) and ISO (2006) defined an output as a product, material, or energy that leaves a UMP. Since the boundaries of a sustainability assessment can range from one process or machine to the entire production system, the definition was expanded to be that which leaves the system boundary, as in the definition for input, above.

\subsubsection{Allocation}

Allocation was defined in reference to ISO (2006). While the McGraw-Hill Dictionary of Scientific and Technical Terms (2003) states, "to assign a portion of a resource to an activity," the ISO definition was selected because it is more applicable to UMP characterization.

\section{(INSERT TABLE 2)}

\subsection{Material Terminology}

Material terminology is used to identify any material, product, or waste that flows into or out of a UMP (Sections 4.3.14.3.6). This includes any material that is used in a UMP, and any product or waste that the UMP generates. These are fundamental to impact, allocation, and functional unit identification. Table 3 presents the harmonized definitions of Material terminology.

\subsubsection{Materials}

Raw materials are described as materials that are used to produce a product (ISO, 2006; Zhang et al., 2015). These are defined as primary (non-recycled) or secondary (recycled) materials (ISO, 2006). Zhang et al. (2015) described raw materials as physical components extracted from the ecosystem and processed into another form of matter to be later used. Most production does not use materials that come directly from the ecosystem. Thus, the term materials was selected to define physical materials from upstream processes, rather than the term raw materials, to remove this implication. Finally, materials can also be auxiliaries, such as solvents and catalysts, and additives; and they can be renewable or recycled.

\subsubsection{Product}

Product was defined using the definition of Zhang et al. (2015).

\subsubsection{Intermediate Product \\ Intermediate product was defined using the definition of ISO (2006).}

\subsubsection{Co-Product}

Co-product was defined using the definition of ISO (2006). Additional discussion is provided in Section 4.3.5.

\subsubsection{By-Product}

By-products of a process may be generated as a result of the desired reaction stoichiometry, a consequence of undesired secondary reactions, or from separating systems (distillation columns). For example, pollutants can be viewed as byproducts of a UMP in the form of unrecovered materials and emissions (Cano-Ruiz and McRae, 1998). By-product composition is worth considering when evaluating the tradeoffs between different processes. For example, considering the reactivity, toxicity, and mass of by-products simultaneously yields a more objective analysis than considering them independently. Lowe (1997), on the other hand, posited that by-products should be reduced at the source when possible, rather than creating markets for dealing with them. For example, Turton et al. (2008) noted that, within an industrial park, 
a by-product is an unwanted resultant stream "that cannot be sold for an overall profit." Taking this view of by-products means that they must be avoided during design, planning, and decision making because by-products are often due to inadequate design or inefficient practices and result in economic losses or environmental impacts for the manufacturer.

In comparison, co-products are useful in some regard and are not considered by-products or waste (see below). Many metallic materials are produced as co-products of other metals processing. For example, cadmium, indium, germanium, and gallium are co-products of zinc production from the mineral sphalerite (Fthenakis et al., 2009). The metals produced are commonly recovered as by-products of zinc production and arise from impurities in the constituent mineral.

\subsubsection{Waste}

Waste was defined using the definition of ISO 14040 (2006), which, in turn, used the definition from the Basel Convention (United Nations, 1989). Emissions and effluents are included as synonyms because these are also of no value to the producer and are usually disposed or released at some cost (e.g., handling or permitting costs). Gaseous or radioactive wastes are commonly identified as emissions, while liquid wastes are identified as effluents. Wastes may or may not be hazardous.

\section{(INSERT TABLE 3)}

\subsection{Measurement Terminology}

Measurement terminology addresses the differences between reporting mechanisms; Sections 4.4.1-4.4.7 address numerical values, whereas Section 4.4.8-4.4.11 address the process. A sustainability assessment is performed to identify the different impacts of a process, system, product, or service. These impacts are reported using three mechanisms: data, metrics, and indicators; where data are the raw measurement values, metrics are a unit of measure used for evaluation, and indicators are meaningful quantitative representations that are used to normalize a set or array of metrics using a characterization factor. The three reporting mechanisms are generally different from process information and parameters because the latter usually directly reveal little about the sustainability of the process. Nevertheless, they indirectly influence sustainability assessment results. The term measurable was included because it is important for the results of a sustainability study to be a quantified entity to assist decision making. The last three terms differentiate the sustainability characterization process, process characterization, and sustainability assessment. Table 4 presents the harmonized definitions of Measurement terminology.

\subsubsection{Impacts}

Impacts was recognized to be a term integral to production process characterization because of its frequent use in definitions developed for the terminology herein. ISO (2006) noted that quantifiable impacts or consequences of process inputs and outputs on human health and the environment can be organized into various impact categories. Zhang et al. (2015) identified economic, environmental, and social weltanschauungen (world views) as different impact domains. Zhao et al. (2012) noted that environmental impacts of products must be reduced through UMP analysis. The definition for impact is generalized to include both positive benefits and negative detriments. Production-related impacts arise as a consequence of UMPs, and can occur on both long and short time scales. Positive impacts include economic, environmental, or social aspects, e.g., cost savings, pollution reduction, and job creation. Negative impacts include reduction of local supplier use, increased water effluents, and increased job hazards.

\subsubsection{Data}

Data was defined using the definition of Veleva and Ellenbecker (2001).

\subsubsection{Metrics}

Metrics are used to track or calculate indicators (US Department of Commerce, 2013; Veleva and Ellenbecker, 2001), and can be used to describe the sustainability performance of a system (Eastwood et al., 2013; Haapala et al., 2013). Different types of evaluation criteria, e.g., midpoints/endpoints and metrics/indicators are used at different levels of system analysis. Due to the associated level of detail, higher-level criteria become abstracted from the process settings as the system analysis broadens. Thus, broader system analysis tends to provide less specific guidance to lower-level solutions. Meaningful values for different decisions are dependent on the abstraction of the decision from the context of the analysis. Metrics are less abstracted than indicators, and will more directly support UMP solutions. For example, to calculate a metric for normalized waste per product, the data collected depends on the type of waste and could be computed either in terms of volume of waste produced per time or mass of waste per time. An example indicator (Section 4.4.4) calculated from the waste metric is human toxicity potential (HTP). HTP represents the potential harm due to the release of a given mass of chemical into the environment based on the toxicity and potential dose of a compound (Hertwich et al., 2001). Emissions can be referenced in terms of benzene (carcinogens) or toluene (noncarcinogens) equivalents. In this example, 
the metric (waste) results provide decision direction, whereas the indicator (HTP) results are inherently opaque and create an interpretation conflict. A higher waste metric value would give the direction to reduce process wastes/emissions. On the other hand, a higher HTP indicator value could be due to increased wastes/emissions or a change in the material/chemical used in production.

\subsubsection{Indicator}

An indicator is a criterion or measure used to quantify information to describe a phenomenon or aspect of a system for business or engineering decision makers (ISO, 2006; Mani et al., 2014; US Department of Commerce, 2013; Veleva and Ellenbecker, 2001; Zhang et al., 2015). Sets of indicators are commonly used to collectively measure sustainability performance (Ruiz-Mercado et al., 2012; US Department of Commerce, 2013). Indicator sets are referred to as indices (Krajnc and Glavič, 2005).

\subsubsection{Characterization Factor}

Characterization factor was defined using the definition of ISO (2006).

\subsubsection{Process Information}

Process information is recognized to be the information related to a UMP (ASTM, 2014; Overcash et al., 2012). Overcash et al. (2012) included the functional unit, time period, geography, and technology, whereas ASTM (2014) included part geometry, key performance indicators (KPIs), material properties, setup and operation instructions, quality plans, and control programs as process information. Process information is a generalized term that includes all information relating to the process and/or process-product interaction.

\subsubsection{Parameters}

Parameters and variables are described as the conditions of a UMP input (Kellens et al., 2012a), attributes of a system (Veleva and Ellenbecker, 2001), or measured properties (US Department of Commerce, 2013). Parameters are a specific kind of process information.

\subsubsection{Measurable}

Measurable was defined using the definition of US Department of Commerce (2013).

\subsubsection{Sustainability Characterization Process}

Sustainability characterization process was defined using the definition of Mani et al. (2014).

\subsubsection{Process Characterization}

Process characterization was defined using the definition of Mani et al. (2014).

\subsubsection{Sustainability Assessment}

Sustainability assessment is included due to its frequency of use within the discussion of this article. It is defined as a consequence of broadening the concept of LCA to include social and economic impacts. Zhang et al. (2015) identified several contributing assessment methods including social impact assessment, environmental impact assessment, and lifecycle costing. Each of these methods can be included under the umbrella of sustainability assessment. Ness et al. (2007) identified three elements pertinent to the definition of sustainability assessment: 1) integration of nature and society, 2) spatial aspects, and 3) temporal aspects.

(INSERT TABLE 4)

\subsection{Model Terminology}

Model terminology addresses the different types of models commonly found in UMP characterization. General model types have been previously defined, and it is not the intention of the authors to include all possible models or equations that can be used for characterization, e.g., specific relationships such as the Navier-Stokes equation are not discussed. The terms included here are unit manufacturing process model, unit process life cycle inventory (UPCLI), in-depth UPLCl, screening UPLCl, manufacturing process flow model, and manufacturing process information model (Sections 4.5.1 and 4.5.3-4.5.7). Two other terms included are composability (Section 4.5.2), which describes model interaction, and taxonomy (Section 4.5.8), which defines different UMPs by function. Table 5 presents the harmonized definitions of the Model terminology. 


\subsubsection{Unit Manufacturing Process Model}

Unit manufacturing process models are developed to explore process and material interactions, and can be used to quantify sustainability metrics (Eastlick and Haapala, 2012). The models are used to relate material and energy inputs to outputs and can account for variations in the process (Eastwood et al., 2013). Models are developed through mechanistic relationships or empirical observation (Eastlick and Haapala, 2012). Model evaluation allows for analysis of product and process designs and investigation for improvement (Eastwood et al., 2013).

\subsubsection{Composability}

Composability was defined after the definition of Davis and Anderson (2004). One goal for unit manufacturing process modeling is the ability to chain different UMP models together to create a production system or product assessment. Automated UMP flow planning and production system optimization using process control could occur if models are capable of interacting with one another. This interaction between models is termed composability.

\subsubsection{Unit Process Life Cycle Inventory (UPLCI)}

A unit process life cycle inventory (UPLCI) contains data for a process resulting from a sustainability study (Kellens et al., 2012b). UPLCl was defined using the definition of Overcash and Twomey (2012). UPLCls are formatted to contain an overview of the process, literature data and references, a parameter selection, $\mathrm{LCl}$ energy calculations, and LCl mass loss calculations (Overcash et al., 2009). UPLCI construction has been formalized in the CO2PE! Method, which can be used to generate UPLCls using either the in-depth approach (Section 4.5.4) or the screening approach (Section 4.5.5) (Kellens et al., 2012b).

\subsubsection{In-Depth UPLCI (CO2PE!)}

The in-depth UPLCI approach of the CO2PE! method generates more accurate UPLCI data than the screening approach (Kellens et al., 2012b). The approach is divided into four studies: time, power, consumables, and emissions studies (Duflou et al., 2012; Kellens et al., 2012a, 2012b). The studies document all relevant process inputs and outputs in detail (Kellens et al., 2012a, 2012b).

\subsubsection{Screening UPLCI (CO2PE!)}

The screening UPLCI approach of the CO2PE! method generates UPLCI data and provides a first insight into a UMP (Kellens et al., 2012b). A screening study would be considered as an initial investigation into a UMP and would define the boundary, a functional unit, machine parameters, and process information (Kellens et al., 2012a). This information is used to generate energy and mass loss calculations (Duflou et al., 2012; Kellens et al., 2012a, 2012b).

\subsubsection{Manufacturing Process Flow Model}

Manufacturing process flow model was defined using the definition of Mani et al. (2014).

\subsubsection{Manufacturing Process Information Model}

Manufacturing process information model was defined using the definition of Mani et al. (2014).

\subsubsection{Taxonomy}

A taxonomy is used to categorize a wide variety of production processes (Duflou et al., 2012). A taxonomy also helps engineers and other production personnel to understand the available processes and to identify methods to manufacture products (Mani et al., 2014). Finally, taxonomies help convey information for production decision making (Mani et al., 2014). Examples include taxonomies defined by the NRC (1995), Todd et al. (1994), and DIN 8580 (German Institute for Standardization, 2003). An in-depth comparison of manufacturing process taxonomies was performed by Mani et al. (2014). Taxonomies for the chemical and process industry either identify the equipment types, e.g., taxonomies reported by Blackadder and Nedderman (1971), Cheremisinoff (2000), and McCabe et al. (2004), or are organized by the specific chemical product. Equipment-based taxonomies are similar to UMP taxonomies, since they are organized by mechanical function. It is more challenging to identify production process counterparts for chemical taxonomies, since they tend to be organized by chemical product.

\section{(INSERT TABLE 5)}

\subsection{Flow Terminology}

Flow terminology defines movement of energy, materials, and information within a production system. Flows are normalized to a functional unit (Section 4.6.1), and are identified by three main types: material flow, energy flow, and information flow (Sections 4.6.2-4.6.5). Fundamental to these flows are the different ways in which they are transformed from one form to another; i.e., material transformation, energy transformation, and information transformation (Sections 
4.6.6-4.6.8). The Flow category definitions below describe discrete material flows, which can be quantified either per time (e.g., $\mathrm{s}^{-1}$ ) or per physical output (e.g., per product); the distinction is dependent on the type of study being performed and the availability of data to the analyst. For example, quantifying the annual material consumption of a production plant may necessitate the use of time-based production flows, i.e., mass flow rates (e.g., in $\mathrm{kg} / \mathrm{s}$ ) from the individual process level. Alternatively, quantifying material-related life cycle impacts would require the use of unit-based production flows, i.e., mass flow rates (e.g., in $\mathrm{kg}$ ) from the individual product level. The transformation definitions below describe the conversion of material, energy, or information inputs within the UMPs to form the outputs. Table 6 presents the harmonized definitions of Flow terminology.

\subsubsection{Functional Unit}

A functional unit is recognized to be a qualitative and quantitative reference unit of a production system (ISO, 2006; Kellens et al., 2012a; Overcash et al., 2012). In manufacturing, the functional unit is, for example, the number of discrete products or mass/volume of continuous product that flows through the production system over a specified time duration and serves to act as a denominator for all process performance measures that are used to evaluate the performance of any UMP in the manufacturing process flow. For a UMP, a functional unit is a quantifiable and qualifiable reference unit indicating the performance of a process (Kellens et al., 2012a), and it can include volume or mass of material removed in a machining process, available equipment (e.g., oven) capacity, or flow rate of a chemical process, among other measures. CO2PE! specifies standard functional units to maintain normalized UPLCI data for various processes (Kellens et al., 2012a).

\subsubsection{Material Flow}

Material flow was defined using the definition of ISO (2006).

\subsubsection{Intermediate Flow}

Intermediate flow was defined using the definition of ISO (2006).

\subsubsection{Energy Flow}

Energy flow was defined using the definition of ISO (2006).

\subsubsection{Information Flow}

Information flow was defined using the definition of Mani et al. (2014).

\subsubsection{Material Transformation}

Material transformation was defined using the definition of ASTM (2014).

\subsubsection{Energy Transformation}

Energy transformation was defined using the definition of ASTM (2014).

\subsubsection{Information Transformation \\ Information transformation was defined using the definition of ASTM (2014).}

(INSERT TABLE 6)

\section{Conclusions and Recommendations}

A common set of terminology is yet to be developed for researchers, scientists, engineers, and decision makers involved in sustainable production. Consequently, it is still not possible to communicate sustainable production process requirements and results across a production system or enterprise. This work takes a step towards identifying the key terms and definitions as they relate to sustainable production. A review of literature related to sustainable production process characterization and modeling was performed to elevate understanding of key concepts and to identify related terminology. Synonyms were identified for key terms by reviewing the relevant literature to clarify and harmonize overlapping definitions. The forty-seven terms identified were organized into six categories, namely, Scope, Boundary, Material, Measurement, Model, and Flow, to extract and organize overarching concepts. The authors observed that a holistic review of research on process characterization and process models in support of sustainable production is yet to be accomplished; such a review would be beneficial, perhaps by organizing prior work by process type using a standard process taxonomy.

This collection of terms is not exhaustive; it is one step towards identifying and standardizing common terminology for sustainable production process characterization. This initial set of terminology can stimulate conversations and communication within production facilities and supply chains to support sustainable production efforts. It is important to 
note that normalizing the language through standard terminology and definitions is critical. This work can also initiate community discussions on standards for production process characterization terminology. Organized discussions could proceed with involvement of researchers and industry practitioners to facilitate consensus on generalized terminology, definitions, procedures, and practice. Such discussions could proceed within small groups (roundtables), conference presentations, panel sessions, or workshops.

Future work includes standardizing the terminology through standards development organizations like ASTM International. Based on the common terminology resulting from conversations among myriad industries, a generalized, sustainability characterization method for production processes should also emerge. Finally, to ensure eventual industry adoption, methods must be formalized in scalable, composable models and implemented in affordable software applications. Such formalization is needed because 1) sustainability assessment requires a broad set of expertise across multiple disciplines, 2) data collection is tedious, and 3) mathematical calculations, especially for complex products and production systems, are non-trivial. Such software will improve sustainable decisions and real-time control of production networks. Each aspect of this work will require intensive effort and collaboration on the part of researchers and practitioners representing a broad set of disciplinary and industrial expertise. Completion of this fundamental research will enable applications of sustainable production process characterization to benefit product improvement, process optimization, and supplier selection activities.

\section{Acronyms}

ACS - American Chemical Society

ASTM - American Society for Testing and Materials

BAT - Best available technology

CO2PE! - Cooperative Effort on Process Emissions in Manufacturing Initiative

CSM - Competitive sustainable manufacturing

DIN - German Institute for Standardization

DOC - Department of Commerce

ECMPRO - Environmentally conscious manufacturing and product recovery

ESET - Economic, social, environmental, and technological

$\mathrm{GCl}$ - Green Chemistry Institute

IMS - Intelligent manufacturing system

ISO - International Organization for Standardization

$\mathrm{KPI}$ - Key performance indicator

LCA - Life cycle assessment

$\mathrm{LCl}$ - Life cycle inventory

MCDA - Multi criteria decision analysis

NIST - National Institutes of Standards and Technology

$\mathrm{NRC}$ - National Research Council

SD-AP - Sustainable development with axiological perspectives

UMP - Unit manufacturing process

UPLCI - Unit process life cycle inventory 


\section{Acknowledgements}

The authors gratefully acknowledge Jon Anderson of Chalmers University of Technology for his input on an early draft of this manuscript. The authors from Oregon State University gratefully acknowledge the National Institute of Standards and Technology (NIST Award No. 70NANB13H155) for its support of this research.

\section{Disclaimer}

Certain products or services are identified in the paper to foster understanding. Such identification does not imply recommendation or endorsement by the National Institute of Standards and Technology, nor does it imply that the products or services identified are necessarily the best available for the purpose.

\section{References}

Allen, D.T., Shonnard, D.R., 2001. Green Engineering: Environmentally Conscious Design of Chemical Processes. Pearson Education.

Anastas, P.T., Zimmerman, J.B., 2003. Design Through the 12 Principles of Green Engineering. Environ. Sci. Technol. 37, 94A-101A. doi:10.1021/es032373g

Arena, M., Ciceri, N.D., Terzi, S., Bengo, I., Azzone, G., Garetti, M., 2009. A State-of-the-Art of Industrial Sustainability: Definitions, Tools and Metrics. International Journal of Product Lifecycle Management 4, $207-251$. doi:10.1504/IJPLM.2009.031674

ASTM, 2016. E3012-16: Standard Guide for Characterizing Environmental Aspects of Manufacturing Processes [WWW Document]. URL http://www.astm.org/Workltems/WK35705.htm (accessed 5.22.14).

ASTM, 2014. WK35705 New Guide for Sustainability Characterization of Manufacturing Processes [WWW Document]. URL http://www.astm.org/Workltems/WK35705.htm (accessed 5.22.14).

Beruvides, M.G., Omachonu, V., 2001. A Systematic Statistical Approach for Managing Research Information: the State of the Art Matrix Analysis, in: Proceedings of 2001 Industrial Engineering Research Conference. Dallas, Texas.

Blackadder, D.A., Nedderman, R.M., 1971. Handbook of Unit Operations, 1st ed. Academic Press Inc, London, New York. Block, S.S., 2001. Disinfection, Sterilization, and Preservation. Lippincott Williams \& Wilkins, Philadelphia, PA.

Bolis, I., Morioka, S.N., Sznelwar, L.I., 2014. When Sustainable Development Risks Losing its Meaning. Delimiting the Concept with a Comprehensive Literature Review and a Conceptual Model. Journal of Cleaner Production 83, 720. doi:10.1016/j.jclepro.2014.06.041

Cano-Ruiz, J.A., McRae, G.J., 1998. Environmentally Conscious Chemical Process Design. Annual Review of Energy and the Environment 23, 499-536. doi:10.1146/annurev.energy.23.1.499

Cheremisinoff, N.P., 2000. Handbook of Chemical Processing Equipment, 1st ed. Butterworth-Heinemann, Boston.

Chiu, M.C., Kremer, G.E.O., 2011. Investigation of the Applicability of Design for X Tools during Design Concept Evolution: a Literature Review. International Journal of Product Development 13, $132-167$. doi:10.1504/IJPD.2011.038869

Dahmus, J.B., Gutowski, T.G., 2004. An Environmental Analysis of Machining, in: ASME 2004 International Mechanical Engineering Congress and Exposition (IMECE2004). Anaheim, CA, pp. 643-652. doi:10.1115/IMECE2004-62600

Davis, P.K., Anderson, R.H., 2004. Improving the Composability of DoD Models and Simulations. The Journal of Defense Modeling and Simulation: Applications, Methodology, Technology 1, 5-17. doi:10.1177/154851290400100101

Defraeye, T., 2014. Advanced Computational Modelling for Drying Processes - A Review. Applied Energy 131, 323-344. doi:10.1016/j.apenergy.2014.06.027

Dincer, I., 2000. Renewable Energy and Sustainable Development: a Crucial Review. Renewable and Sustainable Energy Reviews 4, 157-175. doi:10.1016/S1364-0321(99)00011-8

Dixit, U.S., Joshi, S.N., Davim, J.P., 2011. Incorporation of Material Behavior in Modeling of Metal Forming and Machining Processes: A Review. Materials \& Design 32, 3655-3670. doi:10.1016/j.matdes.2011.03.049

Dornfeld, D.A., Linke, B.S., 2012. Leveraging Technology for a Sustainable World Proceedings of the 19th CIRP Conference on Life Cycle Engineering, University of California at Berkeley. Springer, Heidelberg; New York.

Duflou, J.R., Kellens, K., Dewulf, W., 2011. Unit Process Impact Assessment for Discrete Part Manufacturing: A State of the Art. CIRP Journal of Manufacturing Science and Technology, Energy-Efficient Product and Process Innovations in Production Engineering 4, 129-135. doi:10.1016/j.cirpj.2011.01.008

Duflou, J.R., Sutherland, J.W., Dornfeld, D., Herrmann, C., Jeswiet, J., Kara, S., Hauschild, M., Kellens, K., 2012. Towards Energy and Resource Efficient Manufacturing: A Processes and Systems Approach. CIRP Annals Manufacturing Technology 61, 587-609. doi:10.1016/j.cirp.2012.05.002

Dyllick, T., Hockerts, K., 2002. Beyond the Business Case for Corporate Sustainability. Bus. Strat. Env. 11, $130-141$. doi:10.1002/bse.323

Eastlick, D.D., Haapala, K.R., 2012. Increasing the Utility of Sustainability Assessment in Product Design, in: ASME 2012 International Design Engineering Technical Conferences \& Computers and Information in Engineering Conference. Chicago, IL, pp. 713-722.

Eastwood, M.D., Haapala, K.R., 2015. A Unit Process Model Based Methodology to Assist Product Sustainability Assessment During Design for Manufacturing. Journal of Cleaner Production 108, part A, 54-64. doi:10.1016/j.jclepro.2015.08.105 
Eastwood, M.D., Haapala, K.R., Carter, M.D., Liner, P.W., 2013. Product and Process Design for Sustainable Assembly, in: ASME 2013 International Mechanical Engineering Congress \& Exposition. San Diego, CA.

Ehmann, K.F., Kapoor, S.G., DeVor, R.E., Lazoglu, I., 1997. Machining Process Modeling: A Review. J. Manuf. Sci. Eng. 119, 655-663. doi:10.1115/1.2836805

Elkington, J., 1997. Cannibals with Forks: The Triple Bottom Line of 21st Century Business. Capstone Publishing Ltd, Oxford.

Feng, S.C., Joung, C.B., 2011. A Measurement Infrastructure for Sustainable Manufacturing. International Journal of Sustainable Manufacturing 2, 204-221. doi:10.1504/IJSM.2011.042152

Finnveden, G., Hauschild, M.Z., Ekvall, T., Guinée, J., Heijungs, R., Hellweg, S., Koehler, A., Pennington, D., Suh, S., 2009. Recent Developments in Life Cycle Assessment. Journal of Environmental Management 91, 1-21. doi:10.1016/j.jenvman.2009.06.018

Fthenakis, V., Wang, W., Kim, H.C., 2009. Life Cycle Inventory Analysis of the Production of Metals Used in Photovoltaics. Renewable and Sustainable Energy Reviews 13, 493-517. doi:10.1016/j.rser.2007.11.012

German Institute for Standardization, 2003. DIN 8580: Manufacturing Processes - Definitions, Classification.

Glavič, P., Lukman, R., 2007. Review of Sustainability Terms and Their Definitions. Journal of Cleaner Production 15, 1875-1885. doi:10.1016/j.jclepro.2006.12.006

Gungor, A., Gupta, S.M., 1999. Issues in Environmentally Conscious Manufacturing and Product Recovery: a Survey. Computers \& Industrial Engineering 36, 811-853. doi:10.1016/S0360-8352(99)00167-9

Guo, Y.B., Li, W., Jawahir, I.S., 2009. Surface Integrity Characterization and Prediction in Machining of Hardened and Difficult-to-Machine Alloys: A State-of-Art Research Review and Analysis. Machining Science and Technology 13, 437-470. doi:10.1080/10910340903454922

Gutowski, T.G., Allwood, J.M., Herrmann, C., Sahni, S., 2013. A Global Assessment of Manufacturing: Economic Development, Energy Use, Carbon Emissions, and the Potential for Energy Efficiency and Materials Recycling. Annual Review of Environment and Resources 38, 81-106. doi:10.1146/annurev-environ-041112-110510

Haapala, K.R., Zhao, F., Camelio, J., Sutherland, J.W., Skerlos, S.J., Dornfeld, D.A., Jawahir, I.S., Clarens, A.F., Rickli, J.L., 2013. A Review of Engineering Research in Sustainable Manufacturing. Journal of Manufacturing Science and Engineering 135, 41013-1-41013-16. doi:10.1115/1.4024040

Hahn, R., Kühnen, M., 2013. Determinants of Sustainability Reporting: a Review of Results, Trends, Theory, and Opportunities in an Expanding Field of Research. Journal of Cleaner Production 59, 5-21. doi:10.1016/j.jclepro.2013.07.005

Hauschild, M., Jeswiet, J., Alting, L., 2005. From Life Cycle Assessment to Sustainable Production: Status and Perspectives. CIRP Annals - Manufacturing Technology 54, 1-21. doi:10.1016/S0007-8506(07)60017-1

Hertwich, E.G., Mateles, S.F., Pease, W.S., McKone, T.E., 2001. Human toxicity potentials for life-cycle assessment and toxics release inventory risk screening. Environ. Toxicol. Chem. 20, 928-939.

Hopp, W.J., Spearman, M.L., 2011. Factory Physics, 3rd ed. Waveland Pr Inc, Long Grove, III.

Hossain, K.A., Khan, F.I., Hawboldt, K., 2008. Sustainable Development of Process Facilities: State-of-the-Art Review of Pollution Prevention Frameworks. Journal of Hazardous Materials 150, 4-20. doi:10.1016/j.jhazmat.2007.08.062

Ibáñez-Forés, V., Bovea, M.D., Pérez-Belis, V., 2014. A Holistic Review of Applied Methodologies for Assessing and Selecting the Optimal Technological Alternative from a Sustainability Perspective. Journal of Cleaner Production 70, 259-281. doi:10.1016/j.jclepro.2014.01.082

Ilgin, M.A., Gupta, S.M., 2010. Environmentally Conscious Manufacturing and Product Recovery (ECMPRO): A Review of the State of the Art. J. Environ. Manage. 91, 563-591. doi:10.1016/j.jenvman.2009.09.037

ISO, 2014. ISO Guide 82:2014 Guidelines for Addressing Sustainability in Standards. International Organization for Standardization.

ISO, 2006. ISO 14040:2006, Environmental Management - Life Cycle Assessment - Principles and Framework. International Organization for Standardization.

Jayal, A.D., Badurdeen, F., Dillon Jr., O.W., Jawahir, I.S., 2010. Sustainable Manufacturing: Modeling and Optimization Challenges at the Product, Process and System Levels. CIRP Journal of Manufacturing Science and Technology, Sustainable Development of Manufacturing Systems 2, 144-152. doi:10.1016/j.cirpj.2010.03.006

Jenck, J.F., Agterberg, F., Droescher, M.J., 2004. Products and Processes for a Sustainable Chemical Industry: a Review of Achievements and Prospects. Green Chemistry 6, 544. doi:10.1039/b406854h

Jiménez-González, C., Kim, S., Overcash, M., 2000. Methodology for Developing Gate-to-Gate Life Cycle Inventory Information 5, 153-159. doi:10.1007/BF02978615

Jiménez-González, C., Poechlauer, P., Broxterman, Q.B., Yang, B.-S., am Ende, D., Baird, J., Bertsch, C., Hannah, R.E., Dell'Orco, P., Noorman, H., Yee, S., Reintjens, R., Wells, A., Massonneau, V., Manley, J., 2011. Key Green Engineering Research Areas for Sustainable Manufacturing: A Perspective from Pharmaceutical and Fine Chemicals Manufacturers. Org. Process Res. Dev. 15, 900-911. doi:10.1021/op100327d

Jovane, F., Yoshikawa, H., Alting, L., Boër, C.R., Westkamper, E., Williams, D., Tseng, M., Seliger, G., Paci, A.M., 2008. The Incoming Global Technological and Industrial Revolution Towards Competitive Sustainable Manufacturing. CIRP Annals - Manufacturing Technology 57, 641-659. doi:10.1016/j.cirp.2008.09.010

Kellens, K., 2013. Energy and Resource Efficient Manufacturing - Unit Process Analysis and Optimization (Doctoral Dissertation). University of Leuven, Leuven. 
Kellens, K., Dewulf, W., Overcash, M., Hauschild, M.Z., Duflou, J.R., 2012a. Methodology for Systematic Analysis and Improvement of Manufacturing Unit Process Life Cycle Inventory (UPLCI) CO2PE! Initiative (cooperative effort on process emissions in manufacturing). Part 1: Methodology Description. Int. J. Life Cycle Assess. 17, 69-78. doi:10.1007/s11367-011-0340-4

Kellens, K., Dewulf, W., Overcash, M., Hauschild, M.Z., Duflou, J.R., 2012b. Methodology for Systematic Analysis and Improvement of Manufacturing Unit Process Life Cycle Inventory (UPLCI) CO2PE! Initiative (cooperative effort on process emissions in manufacturing). Part 2: Case Studies. Int. J. Life Cycle Assess. 17, $242-251$. doi:10.1007/s11367-011-0352-0

Krajnc, D., Glavič, P., 2005. How to Compare Companies on Relevant Dimensions of Sustainability. Ecological Economics 55, 551-563. doi:10.1016/j.ecolecon.2004.12.011

Kunz, N.C., Moran, C.J., Kastelle, T., 2013. Conceptualizing "Coupling" for Sustainability Implementation in the Industrial Sector: a Review of the Field and Projection of Future Research Opportunities. Journal of Cleaner Production 53, 69-80. doi:10.1016/j.jclepro.2013.03.040

Larousse, 1995. Larousse Dictionary of Science and Technology. Larousse, New York.

Lowe, E.A., 1997. Creating By-Product Resource Exchanges: Strategies for Eco-Industrial Parks. Journal of Cleaner Production, Industrial Ecology 5, 57-65. doi:10.1016/S0959-6526(97)00017-6

Mani, M., Madan, J., Lee, J.H., Lyons, K.W., Gupta, S.K., 2014. Sustainability Characterization for Manufacturing Processes. International Journal of Production Research 52, 1-18. doi:10.1080/00207543.2014.886788

Marteel, A.E., Davies, J.A., Olson, W.W., Abraham, M.A., 2003. Green Chemistry and Engineering: Drivers, Metrics, and Reduction to Practice. Annual Review of Environment and Resources 28, 401-428. doi:10.1146/annurev.energy.28.011503.163459

McCabe, W., Smith, J., Harriott, P., 2004. Unit Operations of Chemical Engineering, 7th ed. McGraw-Hill Science/Engineering/Math, Boston.

McGraw-Hill, 2003. McGraw-Hill Dictionary of Scientific and Technical Terms, 6th ed. McGraw-Hill, United States.

McLellan, B.C., Corder, G.., Giurco, D., Green, C., 2009. Incorporating Sustainable Development in the Design of Mineral Processing Operations - Review and Analysis of Current Approaches. Journal of Cleaner Production 17, 14141425.

Mihelcic, J.R., Crittenden, J.C., Small, M.J., Shonnard, D.R., Hokanson, D.R., Zhang, Q., Chen, H., Sorby, S.A., James, V.U., Sutherland, J.W., Schnoor, J.L., 2003. Sustainability Science and Engineering: The Emergence of a New Metadiscipline. Environmental Science \& Technology 37, 5314-5324. doi:10.1021/es034605h

Murphy, C.F., Kenig, G.A., Allen, D.T., Laurent, J.-P., Dyer, D.E., 2003. Development of Parametric Material, Energy, and Emission Inventories for Wafer Fabrication in the Semiconductor Industry. Environ. Sci. Technol. 37, 5373-5382. doi:10.1021/es034434g

Ness, B., Urbel-Piirsalu, E., Olsson, L., Anderberg, S., 2007. Categorizing Tools for Sustainability Assessment. Ecological Economics 60, 498-508.

Nikolopoulou, A., lerapetritou, M.G., 2012. Optimal Design of Sustainable Chemical Processes and Supply Chains: A Review. Computers \& Chemical Engineering 44, 94-103. doi:10.1016/j.compchemeng.2012.05.006

Ortiz, O., Castells, F., Sonnemann, G., 2009. Sustainability in the Construction Industry: a Review of Recent Developments Based on LCA. Construction and Building Materials 23, 28-39. doi:10.1016/j.conbuildmat.2007.11.012

Overcash, M., Duflou, J., Kellens, K., Looman, K., Dewulf, W., Sutherland, J., Twomey, J., Isaacs, J., 2012. Unit Process Life Cycle Inventories CO2PE! - UPLCI Workshop.

Overcash, M., Twomey, J., 2012. Unit Process Life Cycle Inventory (UPLCI) - A Structured Framework to Complete Product Life Cycle Studies, in: Dornfeld, D.A., Linke, B.S. (Eds.), Leveraging Technology for a Sustainable World. Springer Berlin Heidelberg, pp. 1-4.

Overcash, M., Twomey, J., Kalla, D., 2009. Unit Process Life Cycle Inventory for Product Manufacturing Operations, in: ASME International Manufacturing Science and Engineering Conference. ASME, West Lafayette, IN, pp. 49-55. doi:10.1115/MSEC2009-84065

Oxford University Press, 2010. Oxford Dictionary of Science. Oxford University Press, New York.

Parris, T.M., Kates, R.W., 2003. Characterizing and Measuring Sustainable Development. Annual Review of Environment and Resources 28, 559-586. doi:10.1146/annurev.energy.28.050302.105551

Press, D., 2007. Industry, Environmental Policy, and Environmental Outcomes. Annual Review of Environment and Resources 32, 317-344. doi:10.1146/annurev.energy.32.031306.102939

Pryshlakivsky, J., Searcy, C., 2013. Fifteen Years of ISO 14040: a Review. Journal of Cleaner Production 57, 115-123. doi:10.1016/j.jclepro.2013.05.038

Ramani, K., Ramanujan, D., Bernstein, W.Z., Zhao, F., Sutherland, J., Handwerker, C., Choi, J.-K., Kim, H., Thurston, D., 2010. Integrated Sustainable Life Cycle Design: A Review. J. Mech. Des. 132, 91004-1-15. doi:10.1115/1.4002308

Reap, J., Roman, F., Duncan, S., Bras, B., 2008a. A Survey of Unresolved Problems in Life Cycle Assessment: Part 1: Goal and Scope and Inventory Analysis. The International Journal of Life Cycle Assessment 13, $290-300$. doi:10.1007/s11367-008-0008-x 
Reap, J., Roman, F., Duncan, S., Bras, B., 2008b. A Survey of Unresolved Problems in Life Cycle Assessment: Part 2: Impact Assessment and Interpretation. The International Journal of Life Cycle Assessment 13, 374-388. doi:10.1007/s11367-008-0009-9

Richardson, B.J., Wood, S., 2006. Environmental Law for Sustainability. Hart Publishing, United Kingdom.

Ruiz-Mercado, G.J., Smith, R.L., Gonzalez, M.A., 2012. Sustainability Indicators for Chemical Processes: I. Taxonomy. Industrial \& Engineering Chemistry Research 51, 2309-2328. doi:10.1021/ie102116e

Rusinko, C., 2007. Green Manufacturing: An Evaluation of Environmentally Sustainable Manufacturing Practices and Their Impact on Competitive Outcomes. IEEE Transactions on Engineering Management 54, 445-454. doi:10.1109/TEM.2007.900806

Seuring, S., Müller, M., 2008. From a Literature Review to a Conceptual Framework for Sustainable Supply Chain Management. Journal of Cleaner Production 16, 1699-1710. doi:16/j.jclepro.2008.04.020

Shreve, R.N., 1954. Unit Processes in Chemical Processing Introduction. Ind. Eng. Chem. 46, 672-672. doi:10.1021/ie50532a025

Todd, R.H., Allen, D.K., Alting, L., 1994. Manufacturing Processes Reference Guide, 1st ed. Industrial Press, New York.

Turton, R., Bailie, R.C., Whiting, W.B., Shaeiwitz, J.A., 2008. Analysis, Synthesis and Design of Chemical Processes. Pearson Education.

United Nations, 1989. Basel Convention on the Control of Transboundary Movements of Hazardous Wastes and Their Disposal. Basel, Switzerland.

US Department of Commerce, 2013. NIST Sustainable Manufacturing Indicators Repository [WWW Document]. URL http://www.mel.nist.gov/msid/SMIR/Indicator_Repository.html (accessed 9.24.13).

US National Research Council, 1995. Unit Manufacturing Processes: Issues and Opportunities in Research. National Academy of Sciences, Washington, D.C.

Veleva, V., Ellenbecker, M., 2001. Indicators of Sustainable Production: Framework and Methodology. Journal of Cleaner Production 9, 519-549. doi:10.1016/S0959-6526(01)00010-5

Westkämper, E., Alting, Arndt, 2000. Life Cycle Management and Assessment: Approaches and Visions Towards Sustainable Manufacturing (keynote paper). CIRP Annals - Manufacturing Technology 49, 501-526. doi:10.1016/S0007-8506(07)63453-2

World Commission on Environment and Development, 1987. Report of the World Commission on Environment and Development, Our Common Future. Oxford University Press, New York, NY.

Zhang, H., Calvo-Amodio, J., Haapala, K.R., 2015. Establishing Foundational Concepts for Sustainable Manufacturing Systems Assessment through Systems Thinking. International Journal of Strategic Engineering Asset Management 2, 249-269. doi:10.1504/IJSEAM.2015.072124

Zhao, F., Murray, V.R., Ramani, K., Sutherland, J.W., 2012. Toward the Development of Process Plans with Reduced Environmental Impacts. Frontiers of Mechanical Engineering. doi:10.1007/s11465-012-0334-3 
Tables

TABLE 1. SCOPE TERMINOLOGY

\begin{tabular}{|c|c|c|c|}
\hline Term & Synonyms & Harmonized Definition & Contributing References \\
\hline $\begin{array}{l}\text { Sustainable } \\
\text { Production }\end{array}$ & $\begin{array}{l}\text { sustainable } \\
\text { manufacturing }\end{array}$ & $\begin{array}{l}\text { The creation of goods or services using a system of } \\
\text { processes that simultaneously addresses economic, } \\
\text { environmental, and social aspects in an attempt to } \\
\text { improve the positive or reduce the negative impacts of } \\
\text { production by means of responsible and conscious } \\
\text { actions. }\end{array}$ & $\begin{array}{l}\text { (Glavič and Lukman, 2007; } \\
\text { Mani et al., 2014; US } \\
\text { Department of Commerce, } \\
\text { 2013; Veleva and Ellenbecker, } \\
\text { 2001; Zhang et al., 2015) }\end{array}$ \\
\hline $\begin{array}{l}\text { Production } \\
\text { System }\end{array}$ & $\begin{array}{l}\text { manufacturing } \\
\text { system, line, cell, } \\
\text { multi-machine system, } \\
\text { multi-machine } \\
\text { ecosystem }\end{array}$ & $\begin{array}{l}\text { An interrelated set or sequence of processes that } \\
\text { transforms natural and human resources into products. }\end{array}$ & $\begin{array}{l}\text { (Glavič and Lukman, 2007; } \\
\text { Mani et al., 2014; US } \\
\text { Department of Commerce, } \\
\text { 2013; US National Research } \\
\text { Council, 1995; Veleva and } \\
\text { Ellenbecker, 2001; Zhang et } \\
\text { al., 2015) }\end{array}$ \\
\hline Hybrid Process & hybrid workstation & $\begin{array}{l}\text { A combination of multiple unit processes into a single } \\
\text { machine. These processes can be analyzed separately, } \\
\text { but do not include unit processes with integrated } \\
\text { support equipment. }\end{array}$ & (Duflou et al., 2012) \\
\hline $\begin{array}{l}\text { Unit } \\
\text { Manufacturing } \\
\text { Process (UMP) }\end{array}$ & $\begin{array}{l}\text { unit operation, unit } \\
\text { process, process, } \\
\text { operation }\end{array}$ & $\begin{array}{l}\text { The smallest elementary manufacturing activity required } \\
\text { for a specific taxonomological transformation and } \\
\text { composed of machines, devices, or equipment. }\end{array}$ & $\begin{array}{l}\text { (Blackadder and Nedderman, } \\
\text { 1971; ISO, 2006; Kellens et al., } \\
\text { 2012a; Mani et al., 2014; } \\
\text { McCabe et al., 2004; Overcash } \\
\text { and Twomey, 2012; US } \\
\text { National Research Council, } \\
\text { 1995; Zhang et al., 2015) }\end{array}$ \\
\hline Sub-process & & $\begin{array}{l}\text { An element of a unit manufacturing process (UMP) that } \\
\text { can be considered auxiliary to the UMP. Similar to a } \\
\text { UMP, a sub-process requires resource inputs and } \\
\text { generates resource outputs; these inputs and outputs } \\
\text { flow from one sub-process to the next within the UMP. }\end{array}$ & (Mani et al., 2014) \\
\hline Machine & $\begin{array}{l}\text { device, equipment, } \\
\text { mechanism, } \\
\text { instrument, tool }\end{array}$ & $\begin{array}{l}\text { A device, piece of equipment, mechanism, or single } \\
\text { machine which performs an elementary action or is } \\
\text { used for an elementary activity. Furthermore, it is a } \\
\text { combination of rigid bodies that performs work or } \\
\text { makes work easier. }\end{array}$ & $\begin{array}{l}\text { (Duflou et al., 2012; Oxford } \\
\text { University Press, 2010; } \\
\text { McGraw-Hill, 2003; Larousse, } \\
\text { 1995) }\end{array}$ \\
\hline $\begin{array}{l}\text { Continuous } \\
\text { Manufacturing } \\
\text { Process }\end{array}$ & $\begin{array}{l}\text { continuous process, } \\
\text { continuous UMP, } \\
\text { continuous operation }\end{array}$ & $\begin{array}{l}\text { "Production processes in which the output can be } \\
\text { identified and is measurable by mass [flow rate] or } \\
\text { volume [flow rate] as in process industry rather than in } \\
\text { distinct units." }\end{array}$ & (Duflou et al., 2012) \\
\hline $\begin{array}{l}\text { Discrete Part } \\
\text { Manufacturing } \\
\text { Process }\end{array}$ & $\begin{array}{l}\text { discrete process, } \\
\text { discrete part process, } \\
\text { discrete UMP }\end{array}$ & $\begin{array}{l}\text { "Production processes in which the output can be } \\
\text { identified and is measurable in distinct units rather than } \\
\text { by mass [flow rate] or volume [flow rate] as in process } \\
\text { industry." }\end{array}$ & (Duflou et al., 2012) \\
\hline $\begin{array}{l}\text { Batch } \\
\text { Manufacturing } \\
\text { Process }\end{array}$ & $\begin{array}{l}\text { batch process, batch } \\
\text { UMP, batch operation }\end{array}$ & $\begin{array}{l}\text { A simultaneous batch process, where components are } \\
\text { produced simultaneously, e.g., a heat treatment } \\
\text { process, rather than sequentially. Batching occurs in } \\
\text { the processing of the materials rather than during } \\
\text { material transport. }\end{array}$ & (Hopp and Spearman, 2011) \\
\hline
\end{tabular}


TABLE 2. BOUNDARY TERMINOLOGY

\begin{tabular}{|c|c|c|c|}
\hline Term & Synonyms & Harmonized Definition & Contributing References \\
\hline Boundaries & $\begin{array}{l}\text { system } \\
\text { boundaries }\end{array}$ & $\begin{array}{l}\text { A set of criteria specifying the scope of a study that identifies the level of } \\
\text { detail, e.g., machines, sub-processes, processes, production system, } \\
\text { inputs, outputs, and flows included in the study. Set boundaries are used } \\
\text { to identify the extent to which an assessment starts and stops. Studies } \\
\text { with specific boundaries can be used in unison to perform more vertical } \\
\text { assessments. }\end{array}$ & $\begin{array}{l}\text { (Duflou et al., 2012, 2011; } \\
\text { ISO, 2006; Kellens et al., } \\
\text { 2012a; Veleva and } \\
\text { Ellenbecker, 2001; Zhang et } \\
\text { al., 2015) }\end{array}$ \\
\hline Input & & $\begin{array}{l}\text { Material, energy, or information that enters the boundaries of the defined } \\
\text { system. Includes intermediate products (including co-products, by- } \\
\text { products), raw materials, or any upstream material flow. }\end{array}$ & $\begin{array}{l}\text { (Haapala et al., 2013; ISO, } \\
2006)\end{array}$ \\
\hline $\begin{array}{l}\text { Ancillary } \\
\text { Input }\end{array}$ & & $\begin{array}{l}\text { "Material input that is used by the unit process producing the product, but } \\
\text { which does not constitute part of the product." }\end{array}$ & $(\mathrm{ISO}, 2006)$ \\
\hline Output & & $\begin{array}{l}\text { Products, material, energy, or information that leaves the boundaries of } \\
\text { the defined system. Includes co-products, by-products, intermediate } \\
\text { products, emissions, effluents, and wastes which enter other industrial or } \\
\text { natural systems. }\end{array}$ & $\begin{array}{l}\text { (Haapala et al., 2013; ISO, } \\
2006)\end{array}$ \\
\hline Allocation & & $\begin{array}{l}\text { "Partitioning the input or output flows of a process or a product system } \\
\text { between the product system under study and one or more other product } \\
\text { systems." }\end{array}$ & (ISO, 2006) \\
\hline
\end{tabular}

TABLE 3. MATERIAL TERMINOLOGY

\begin{tabular}{|c|c|c|c|}
\hline Term & Synonyms & Harmonized Definition & Contributing References \\
\hline Materials & raw materials & $\begin{array}{l}\text { Any physical material used to produce a product. Primary material } \\
\text { includes the material from initial extraction and processing, and } \\
\text { secondary material includes recycled content which has undergone } \\
\text { reprocessing. }\end{array}$ & $\begin{array}{l}\text { (ISO, 2006; Zhang et al., } \\
\text { 2015) }\end{array}$ \\
\hline Product & & $\begin{array}{l}\text { "Any good or service offered to serve the needs of other members of } \\
\text { society." }\end{array}$ & $\begin{array}{l}\text { (Zhang et al., 2015)*, (ISO, } \\
\text { 2006) }\end{array}$ \\
\hline $\begin{array}{l}\text { Intermediate } \\
\text { Product }\end{array}$ & & $\begin{array}{l}\text { "Output from a unit process that is input to other unit processes that } \\
\text { requires further transformation within the system." }\end{array}$ & (ISO, 2006) \\
\hline Co-product & & $\begin{array}{l}\text { "Any of two or more products coming from the same unit process or } \\
\text { product system." }\end{array}$ & (ISO, 2006) \\
\hline By-product & & $\begin{array}{l}\text { An undesired material, in any phase (gas, liquid, solid), output from a } \\
\text { unit process that results in economic losses or environmental } \\
\text { impacts. }\end{array}$ & $\begin{array}{l}\text { (Cano-Ruiz and McRae, } \\
\text { 1998; Lowe, 1997; Turton et } \\
\text { al., 2008) }\end{array}$ \\
\hline Waste & $\begin{array}{l}\text { emissions, } \\
\text { effluents }\end{array}$ & $\begin{array}{l}\text { "Substances or objects which the holder intends or is required to } \\
\text { dispose." }\end{array}$ & $\begin{array}{l}\text { (ISO, 2006; Zhang et al., } \\
\text { 2015), (United Nations, } \\
1989)^{*}\end{array}$ \\
\hline
\end{tabular}


TABLE 4. MEASUREMENT TERMINOLOGY

\begin{tabular}{|c|c|c|c|}
\hline Term & Synonyms & Harmonized Definition & $\begin{array}{c}\text { Contributing } \\
\text { References }\end{array}$ \\
\hline Impacts & sustainability results & $\begin{array}{l}\text { The results or outcomes of an assessment or study that } \\
\text { quantify social, economic, and environmental } \\
\text { consequences and which are described and identified } \\
\text { using data, metrics, or indicators. Impacts can be both } \\
\text { positive and negative. }\end{array}$ & $\begin{array}{l}\text { (ISO, 2006; Zhang et al., } \\
\text { 2015; Zhao et al., 2012) }\end{array}$ \\
\hline Data & measurements & "Actual measurements of observations of a variable." & $\begin{array}{l}\text { (Veleva and Ellenbecker, } \\
\text { 2001) }\end{array}$ \\
\hline Metric & $\begin{array}{l}\text { measure, performance } \\
\text { metric, performance } \\
\text { measure, midpoint }\end{array}$ & $\begin{array}{l}\text { A unit of measure used in evaluating a system, } \\
\text { machine, process, or sub-process. Metrics are used to } \\
\text { calculate an indicator. A variety of metrics are } \\
\text { commonly used to assess the economic, environmental, } \\
\text { and social aspects of sustainability. Metrics are selected } \\
\text { and evaluated based on end user needs and the scope } \\
\text { or level of assessment. }\end{array}$ & $\begin{array}{l}\text { (Eastwood et al., 2013; } \\
\text { Haapala et al., 2013; US } \\
\text { Department of } \\
\text { Commerce, 2013; Veleva } \\
\text { and Ellenbecker, 2001) }\end{array}$ \\
\hline Indicator & $\begin{array}{l}\text { impact category, category } \\
\text { indicator, key } \\
\text { performance indicator } \\
\text { (KPI), composite } \\
\text { indicator/index, endpoint }\end{array}$ & $\begin{array}{l}\text { A meaningful variable or parameter that describes or } \\
\text { provides information about a production process or } \\
\text { production system. Multiple indicators are typically used } \\
\text { for an evaluation. Metrics are used to calculate an } \\
\text { indicator. }\end{array}$ & $\begin{array}{l}\text { (ISO, 2006; Mani et al., } \\
\text { 2014; US Department of } \\
\text { Commerce, 2013; Veleva } \\
\text { and Ellenbecker, 2001; } \\
\text { Zhang et al., 2015) }\end{array}$ \\
\hline $\begin{array}{l}\text { Characterization } \\
\text { Factor }\end{array}$ & conversion factor & $\begin{array}{l}\text { "Factor derived from a characterization model which is } \\
\text { applied to convert an assigned life cycle inventory } \\
\text { analysis result to the common unit of the category } \\
\text { indicator. The common unit allows calculation of the } \\
\text { category indicator result." }\end{array}$ & $(\mathrm{ISO}, 2006)$ \\
\hline $\begin{array}{l}\text { Process } \\
\text { Information }\end{array}$ & & $\begin{array}{l}\text { Description of the unit manufacturing process and } \\
\text { description of the product relating to that process. This } \\
\text { includes any information related to the product or } \\
\text { process in reference to the functional unit and that } \\
\text { process. }\end{array}$ & $\begin{array}{l}\text { (ASTM, 2014; Overcash } \\
\text { et al., 2012) }\end{array}$ \\
\hline Parameters & variables & $\begin{array}{l}\text { Conditions, attributes, or settings of a production } \\
\text { process that can be varied to affect the process and } \\
\text { performance of that process. }\end{array}$ & $\begin{array}{l}\text { (Kellens et al., 2012a; US } \\
\text { Department of } \\
\text { Commerce, 2013; Veleva } \\
\text { and Ellenbecker, 2001) }\end{array}$ \\
\hline Measurable & & $\begin{array}{l}\text { "Capable of being measured quantitatively or } \\
\text { qualitatively in multi-dimensional perspectives, e.g., } \\
\text { economic, social, environmental, technical, etc." }\end{array}$ & $\begin{array}{l}\text { (US Department of } \\
\text { Commerce, 2013) }\end{array}$ \\
\hline $\begin{array}{l}\text { Sustainability } \\
\text { Characterization } \\
\text { Process }\end{array}$ & $\begin{array}{l}\text { sustainability } \\
\text { measurement process }\end{array}$ & $\begin{array}{l}\text { "A sequence of operations, with the necessary } \\
\text { instruments and tools and having the objective of } \\
\text { determining the value of an indicator." }\end{array}$ & (Mani et al., 2014) \\
\hline $\begin{array}{l}\text { Process } \\
\text { Characterization }\end{array}$ & $\begin{array}{l}\text { production process } \\
\text { characterization, process } \\
\text { sustainability } \\
\text { characterization }\end{array}$ & $\begin{array}{l}\text { "A process characterization activity typically identifies } \\
\text { key inputs and outputs of a process, collects data over } \\
\text { the entire operating range, estimates the steady-state } \\
\text { behavior at optimal operating conditions and builds } \\
\text { models describing the parametric relationships across } \\
\text { the operating range. A process characterization activity } \\
\text { results in a set of mathematical process models that } \\
\text { can be used to monitor and improve the process." }\end{array}$ & (Mani et al., 2014) \\
\hline $\begin{array}{l}\text { Sustainability } \\
\text { Assessment }\end{array}$ & $\begin{array}{l}\text { sustainability analysis, } \\
\text { sustainability study, } \\
\text { system performance } \\
\text { analysis }\end{array}$ & $\begin{array}{l}\text { A methodological examination of a system, process, or } \\
\text { product undertaken to understand the associated } \\
\text { economic, environmental, and social impacts, with } \\
\text { respect to a specific scope and time scale. }\end{array}$ & $\begin{array}{l}\text { (ISO, 2006; Ness et al., } \\
\text { 2007; Zhang et al., 2015) }\end{array}$ \\
\hline
\end{tabular}


TABLE 5. MODEL TERMINOLOGY

\begin{tabular}{|c|c|c|c|}
\hline Term & Synonyms & Harmonized Definition & $\begin{array}{c}\text { Contributing } \\
\text { References }\end{array}$ \\
\hline $\begin{array}{l}\text { Unit } \\
\text { Manufacturing } \\
\text { Process Model }\end{array}$ & $\begin{array}{l}\text { unit process model, } \\
\text { UMP model }\end{array}$ & $\begin{array}{l}\text { Several mathematical models developed for a specific unit } \\
\text { manufacturing process to evaluate a particular set of metrics or } \\
\text { indicators. Models can be developed from mechanistic } \\
\text { relationships or empirical measurement and observation. Models } \\
\text { should account for all inputs and outputs of the process. }\end{array}$ & $\begin{array}{l}\text { (Eastlick and } \\
\text { Haapala, 2012; } \\
\text { Eastwood et al., } \\
\text { 2013) }\end{array}$ \\
\hline Composability & & $\begin{array}{l}\text { The capability to select and assemble models in various ways to } \\
\text { represent a process flow, or the capability of the models to } \\
\text { represent different process scales. Models can be individually or } \\
\text { combinatorially assessed to identify the impacts at different levels } \\
\text { of production, e.g., a sub-process, a unit manufacturing process, } \\
\text { or a production system. }\end{array}$ & $\begin{array}{l}\text { (Davis and Anderson, } \\
2004 \text { ) }\end{array}$ \\
\hline $\begin{array}{l}\text { Unit Process Life } \\
\text { Cycle Inventory } \\
\text { (UPLCl) }\end{array}$ & & $\begin{array}{l}\text { A process characterization reporting framework that contains data, } \\
\text { equations, results, an example for a specific process and } \\
\text { functional unit interaction, and references. Data includes process } \\
\text { descriptions, figures, pictures, energy calculations, and physical } \\
\text { and energy property tables. Equations calculate mass loss and } \\
\text { energy requirements using ancillary inputs and process } \\
\text { information. The example of the UPLCI is for a specific workpiece, } \\
\text { process, or machine. }\end{array}$ & $\begin{array}{l}\text { (Kellens et al., } \\
\text { 2012a), (Overcash } \\
\text { and Twomey, 2012), } \\
\text { (Overcash et al., } \\
\text { 2009) }\end{array}$ \\
\hline $\begin{array}{l}\text { In-depth UPLCI } \\
\text { (CO2PE!) }\end{array}$ & $\begin{array}{l}\text { in-depth systematic } \\
\text { inventory analysis, } \\
\text { in-depth approach }\end{array}$ & $\begin{array}{l}\text { A process characterization method that includes four studies of a } \\
\text { specific machine: time, power, consumables, and emissions. } \\
\text { Results in materials and energy input and output (LCI) data of a } \\
\text { unit manufacturing process utilizing that machine. Can be } \\
\text { considered a method to develop unit process models. }\end{array}$ & $\begin{array}{l}\text { (Duflou et al., 2012; } \\
\text { Kellens et al., 2012a, } \\
\text { 2012b) }\end{array}$ \\
\hline $\begin{array}{l}\text { Screening UPLCI } \\
\text { (CO2PE!) }\end{array}$ & $\begin{array}{l}\text { screening } \\
\text { systematic inventory } \\
\text { analysis, screening } \\
\text { approach }\end{array}$ & $\begin{array}{l}\text { A process characterization method that approximates } \mathrm{LCI} \text { input } \\
\text { and output data using representative energy calculations and } \\
\text { mass loss calculations reported in literature. Can be considered a } \\
\text { method to develop unit process models. }\end{array}$ & $\begin{array}{l}\text { (Duflou et al., 2012; } \\
\text { Kellens et al., 2012a, } \\
\text { 2012b) }\end{array}$ \\
\hline $\begin{array}{l}\text { Manufacturing } \\
\text { Process Flow } \\
\text { Model }\end{array}$ & & $\begin{array}{l}\text { "Describes the dataflow (e.g., inputs, outputs, reference and } \\
\text { control flows) and precedency in manufacturing processes. An } \\
\text { example is the Systems Integration for Manufacturing Applications } \\
\text { (SIMA) reference architecture. The data flow in activity models can } \\
\text { be entities in information models." }\end{array}$ & (Mani et al., 2014) \\
\hline $\begin{array}{l}\text { Manufacturing } \\
\text { Process } \\
\text { Information } \\
\text { Model }\end{array}$ & & $\begin{array}{l}\text { "Defines relationships between sustainability performance and } \\
\text { information related to manufacturing processes (e.g., resources, } \\
\text { tooling materials, and energy). Defines entities and their } \\
\text { relationships. Can include multiple levels, e.g., class or property, } \\
\text { and can include mathematical representations." }\end{array}$ & (Mani et al., 2014). \\
\hline Taxonomy & $\begin{array}{l}\text { manufacturing } \\
\text { process taxonomy }\end{array}$ & $\begin{array}{l}\text { An ordered manufacturing process classification used to identify } \\
\text { specific unit manufacturing processes by their function or } \\
\text { attributes. }\end{array}$ & $\begin{array}{l}\text { (Duflou et al., 2012; } \\
\text { Mani et al., 2014) }\end{array}$ \\
\hline
\end{tabular}


TABLE 6. FLOW TERMINOLOGY

\begin{tabular}{|l|l|l|l|}
\hline \multicolumn{1}{|c|}{ Term } & Synonyms & \multicolumn{1}{|c|}{ Harmonized Definition } & \multicolumn{1}{c|}{$\begin{array}{c}\text { Contributing } \\
\text { References }\end{array}$} \\
\hline Functional Unit & $\begin{array}{l}\text { reference } \\
\text { unit }\end{array}$ & $\begin{array}{l}\text { A qualitative and quantitative reference unit of a production system or } \\
\text { UMP that is used to normalize performance metrics across the } \\
\text { manufacturing system or UMP for a specific product. }\end{array}$ & $\begin{array}{l}\text { (ISO, 2006; Kellens et } \\
\text { al., 2012a; Overcash } \\
\text { et al., 2012) }\end{array}$ \\
\hline Material Flow & & "Products entering from or leaving to another product system." & (ISO, 2006) \\
\hline Intermediate Flow & & $\begin{array}{l}\text { "Material, energy, or information flow occurring between unit processes } \\
\text { of the product system being studied." }\end{array}$ & (ISO, 2006) \\
\hline Energy Flow & $\begin{array}{l}\text { "Input to or output from a unit process or product system, quantified in } \\
\text { energy units. Can be called input or output energy." }\end{array}$ & (ISO, 2006) \\
\hline Information Flow & $\begin{array}{l}\text { "Inputs, outputs, reference and control flows. Can be entities in } \\
\text { information models." }\end{array}$ & $\begin{array}{l}\text { Can include mass change, phase change, structure change, } \\
\text { deformation, and consolidation. }\end{array}$ \\
\hline $\begin{array}{l}\text { Material } \\
\text { Transformation }\end{array}$ & $\begin{array}{l}\text { Can include chemical, electrical, thermal, mechanical, and } \\
\text { electromagnetic sources. }\end{array}$ \\
\hline $\begin{array}{l}\text { Energy } \\
\text { Transformation }\end{array}$ & $\begin{array}{l}\text { "Input information undergoes changes that can include efforts such as } \\
\text { data reduction, conversion, translation, and augmentation. This could } \\
\text { result in changes to items such as production metrics (e.g., throughput } \\
\text { Information } \\
\text { Transformation } \\
\text { energy, material, water, emissions, and waste)." }\end{array}$ & (ASTM, 2014) \\
\hline
\end{tabular}

\section{Figures}

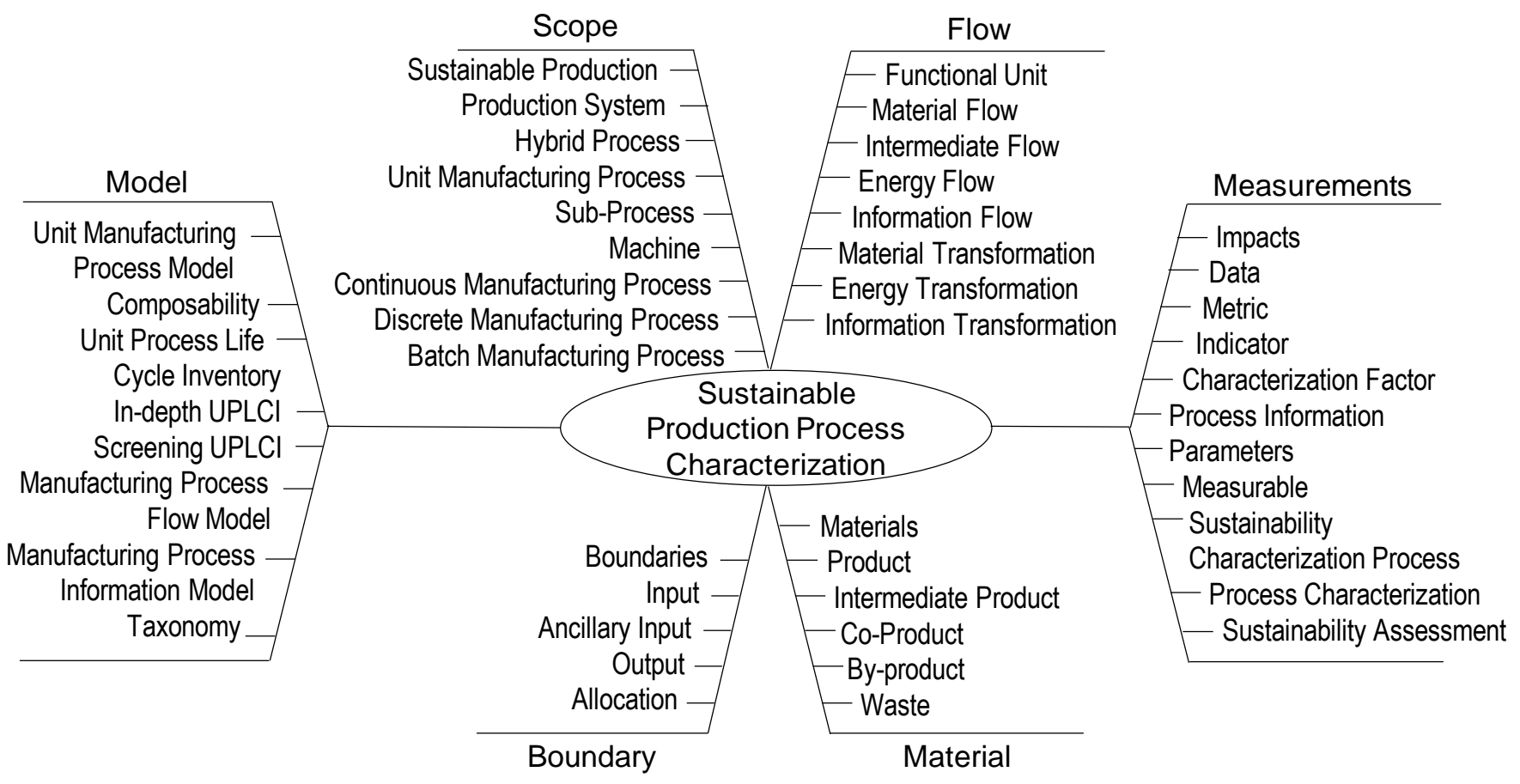

FIGURE 1. CATEGORIZATION OF IDENTIFIED TERMINOLOGY FOR DEFINITIONS. 